\title{
Lung Cancer (LC) in HIV Positive Patients: Pathogenic Features and Implications for Treatment
}

\author{
Stefano Frega ${ }^{1}$, Alessandra Ferro ${ }^{1,2}$, Laura Bonanno ${ }^{1}{ }^{\circledR}$, Valentina Guarneri ${ }^{1,2}$, \\ PierFranco Conte ${ }^{1,2}$ and Giulia Pasello ${ }^{1, *}$ \\ 1 Medical Oncology 2, Istituto Oncologico Veneto IOV- IRCCS, 35, 128 Padova, Italy; \\ stefano.frega@iov.veneto.it (S.F.); alessandra.ferro@iov.veneto.it (A.F.); laura.bonanno@iov.veneto.it (L.B.); \\ valentina.guarneri@unipd.it (V.G.); pierfranco.conte@unipd.it (P.C.) \\ 2 Department of Surgery, Oncology and Gastroenterology, University of Padova, 35, 128 Padova, Italy \\ * Correspondence: giulia.pasello@iov.veneto.it; +390498215931
}

Received: 12 January 2020; Accepted: 21 February 2020; Published: 26 February 2020

\begin{abstract}
The human immunodeficiency virus (HIV) infection continues to be a social and public health problem. Thanks to more and more effective antiretroviral therapy (ART), nowadays HIV-positive patients live longer, thus increasing their probability to acquire other diseases, malignancies primarily. Senescence along with immune-system impairment, HIV-related habits and other oncogenic virus co-infections increase the cancer risk of people living with HIV (PLWH); in the next future non-AIDS-defining cancers will prevail, lung cancer (LC) in particular. Tumor in PLWH might own peculiar predictive and/or prognostic features, and antineoplastic agents' activity might be subverted by drug-drug interactions (DDIs) due to concurrent ART. Moreover, PLWH immune properties and comorbidities might influence both the response and tolerability of oncologic treatments. The therapeutic algorithm of LC, rapidly and continuously changed in the last years, should be fitted in the context of a special patient population like PLWH. This is quite challenging, also because HIV-positive patients have been often excluded from participation to clinical trials, so that levels of evidence about systemic treatments are lower than evidence in HIV-uninfected individuals. With this review, we depicted the epidemiology, pathogenesis, clinical-pathological characteristics and implications for LC care in PLWH, offering a valid focus about this topic to clinicians.
\end{abstract}

Keywords: HIV; PLWH; lung cancer; chemotherapy; immunotherapy

\section{HIV and Cancer Risk}

The human immunodeficiency virus (HIV) infection remains an important global health issue. Despite a progressive decrease of new cases of HIV infection in Europe, this reduction is far from the target identified by the WHO for 2020. Data from Global HIV/AIDS statistics evidence that in 2018, worldwide estimation of people living with HIV (PLWH) was 37.9 million [32.7-44.0 million] with 1.7 million people becoming newly infected in 2018 globally. Among them, about 23.3 million were accessing antiretroviral therapy (ART), up from around 8 million in 2010. Thanks to highly active antiretroviral therapy (HAART), the morbidity and mortality of HIV-infected individuals reduced in last years, indeed, since the peak in 2004, AIDS-related deaths are almost halved [1].

PLWH are at higher risk for cancer than common people, suggesting that HIV is an independent risk factor for its development [2]. In the initial phase of the AIDS epidemic, non-Hodgkin lymphoma (NHL), cervical premalignant lesions and Kaposi sarcoma (KS) were the prevalent form of cancer, and connected to immune-deficient status of PLWH [3]. Accordingly, in 1990, the US Centers for Disease Control defined these malignancies as AIDS-defining cancers (ADCs) [4]. 
With the development in medical care for HIV infection and the widespread use of HAART, the outcome of PLWH has dramatically improved, in part also as a consequence of a decreased rate and mortality from different HIV-related illness, such as ADCs [5]. As this regard, data from the USA registers, showed that Kaposi sarcoma and NHL cases dropped by more than $80 \%$ and $50 \%$ from 1991-1995 to 2001-2005, respectively [6]. However, PLWH still remain at higher risk for ADCs in comparison to the general population, according to recent studies $[7,8]$.

Improving life expectancy, the spectrum of malignancies occurring in PLWH changed substantially in last years: in particular, the incidence of several non-AIDS-defining cancers (NADCs) such as lung cancer (LC), Hodgkin's disease, anal carcinoma, skin cancer, gastrointestinal carcinoma were found to be higher in PLWH than in people without infection [9]. Especially in developed countries, the leading cause of deaths in PLWH has gradually become cancer, and predominantly NADCs in place of ADCs [10]. Moreover, forecasts for the next years provide for LC and prostate expected to emerge as the most common malignancies types by 2030 [11].

\section{Lung Cancer Features in HIV Infected Patients}

LC is both the leading NADCs and the main cause of death from cancers among HIV-positive people [12]. Incidence of LC in HIV-positive patients is remarkable; standardized incidence ratios (SIRs) for LC resulted more than 2.5 higher in PLWH in comparison to the general population, according to two meta-analyses $[3,13]$.

The mechanisms driving increased LC risk among PLWH can be several: (I) tobacco smoking is a quite frequent habit, usually higher than in HIV-negative individuals [14,15]; (II) HIV infection leads to a chronic inflammation and often increases the risk of other viruses co-infections, thus negatively modulating the immune-system [16-18]; and (III) today life-expectancy of PLWH has improved, but elderly increases the risk to cancer due to immune-senescence [19] (Figure 1). It is important to specify that, independent of smoking, PLWH are estimated to have at least two-fold higher risk than HIV-negative individuals to develop LC [20].

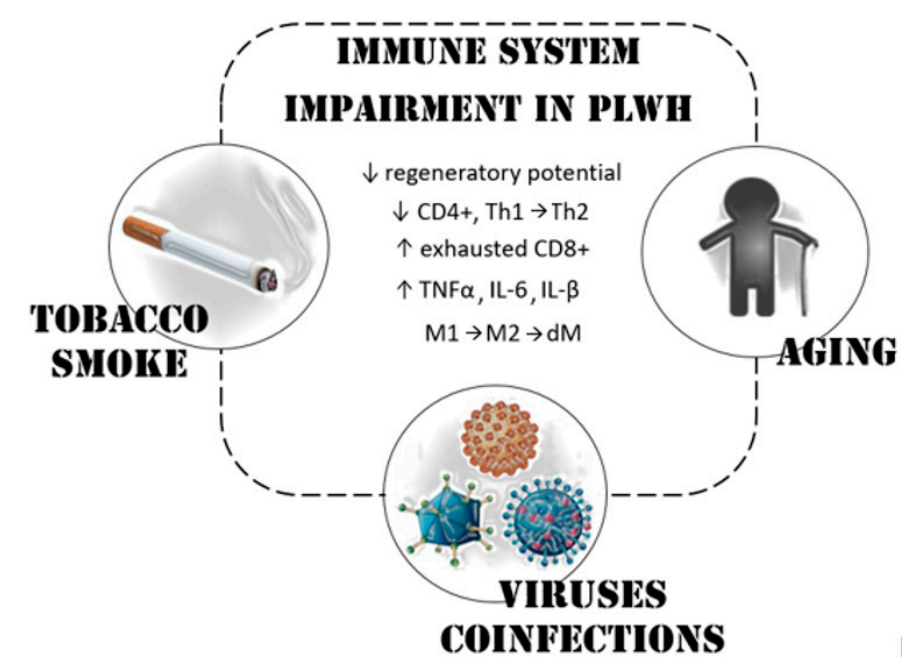

Figure 1. Pathogenesis of LC in people living with HIV (PLWH). Immune system evasion represents the main risk factor for cancer in HIV-positive patients. PLWH constitutively have a strong Th2-humoral oriented immunity, an augmented expression of alternatively activated macrophages (M2) and cytokines responsible of chronic inflammation. These features, together with the impairment of both $\mathrm{T}$ lymphocytes pool and function, are linked not only to the HIV infection itself; also, the quite common tobacco smoke habits, oncogenic viruses coinfections (Epstein-Barr virus, hepatitis B virus, hepatitis $\mathrm{C}$ virus, Kaposi sarcoma herpesvirus) and immune-senescence of nowadays long-survivor PLWH contribute to their higher risk of LC onset. dM: deactivation of macrophages; M1: classically activated macrophages; Th1: type $1 \mathrm{~T}$ helper; Th2: type $2 \mathrm{~T}$ helper. 
Primary prevention would be extremely important, since smoking reduces life expectancy of PLWH because of the higher rate of death due to cardiovascular diseases and NADCs [21]. In particular, LC in PLWH represents nearly a third of deaths from malignancies and about $10 \%$ of non-HIV-related deaths causes [22,23].

Anticancer surveillance of PLWH fails in both humoral responses and in T-cell mediated cytotoxicity (Figure 1). Beyond tobacco smoke and immune system impairment, other risk factors may be implied in NADCs genesis. Age represents one of main single risk factor for cancer in the general population. Elderly and, in particular, the time passed since the HIV infection, raise the cancer risk of PLWH [24,25]. A possible teratogenic potential of HAART was supposed but, despite a few reported associations between certain classes of HAART drug and cancer, future studies are necessary to establish a direct carcinogenic role [26,27].

Regarding clinical characteristics, the disease is often diagnosed in locally advanced/metastatic stage in PLWH and lung adenocarcinoma (LADC) is the most common histological subtype [28].

HIV-infection status seems not to correlate with histotype and disease stage of LC $[29,30]$ and, while controversial data in this regard have been reported [31], even more recent large cohort studies confirmed that distributions of the cancer stage at presentation and histologic subtypes are similar by HIV status [32,33].

PLWH seem to be younger when diagnosed with LC, in comparison with HIV-negative people, probably because they tend to develop malignancies earlier [32]. The HIV-linked pathogenic patterns of cancer initiation and progression, as well as the greater medical surveillance of HIV-positive people versus those HIV-negative might be the factors at the basis of this earlier age at LC diagnosis.

Concerning the molecular features, Thaler et al. found that LADC tumor cells of HIV-positive patients $(n=55)$ express EGFR or KRAS mutations not differently in terms of frequency when compared with those from HIV-negative patients $(n=136)$ [34]. The existence of HIV infection should not negatively influence the search for other druggable targets, such as anaplastic lymphoma kinase (ALK) rearrangement, already described in PLWH affected by non-small cell lung cancer (NSCLC) [35].

It is quite unexplored whether peculiar carcinogenic pathways promote LC initiation and progression in HIV-positive patients. The up-to-date most important contribution comes from Zheng et al., who performed a sophisticated genome-wide analysis on LC specimen by HIV-positive patients $(n=59)$. Proming 1 (PROM1), sineoculis homeobox homolog 1 (SIX1) and transcription factor AP-2 alpha (TFAP2A) genes have been found as overexpressed in LC cells from HIV-positive patients, while synaptopodin-2 (SYNPO2), alcohol dehydrogenase 1B (ADH1B) and indolethylamine N-methyltransferase (INMT) genes resulted as repressed in HIV-associated LC [36]. All these genes are known to be altered in LC tumor-initiating cells, as well as in tumorigenicity through epithelial-mesenchymal transition (EMT) pathway and metastasization process, and these findings may be useful to improve the diagnostic-therapeutic pathway of HIV-associated LC [37,38].

Thus, both etiopathogenesis and prognosis of LC in PLWH might be influenced by a differential expression of key oncogene and tumor suppressor signaling networks. Furthermore, specific immune-suppressor proteins encoded by HIV lentivirus, such as the negative regulator factor (NEF), prevent lung cell apoptosis, thus facilitating cancer initiation [39].

Different cohort studies and a meta-analysis showed that HIV-infection is a negative prognostic factor for different types of malignancies, including LC [32,40-43]. Possible explanations of this historical worst prognosis may be traced in the HIV-linked immunosuppression, as well as major healthcare disparities $[28,44]$, both however improved in last years, thanks to a more active HAART regimen and a wider access to oncologic care. The major above-mentioned HIV-linked LC peculiarities are briefly reported in Table 1, while implications for LC treatments by HIV status are discussed in detail below. 
Table 1. Epidemiology, clinical-pathological characteristics and prognosis of lung cancer in HIV positive people compared to the general population. The table represents in summary those current available data about lung cancer epidemiology, features and prognosis that may differ between HIV-infected and uninfected individuals. HIV seems to have a prognostic value, meanwhile no clear difference by HIV-status emerges in terms of efficacy of oncologic treatments (see the text).

\begin{tabular}{ccccc}
\hline Lung Cancer Features & Subgroups & $\begin{array}{c}\text { HIV }+ \\
\text { Patients }\end{array}$ & $\begin{array}{c}\text { General } \\
\text { Population }\end{array}$ & References \\
\hline $\begin{array}{c}\text { Standardized } \\
\text { incidence ratio (SIR) }\end{array}$ & - & $2.6(2.1-3.1)$ & - & $\begin{array}{c}\text { Shiels MS et al. J Acquir } \\
\text { Immune Defic Syndr 2009 }\end{array}$ \\
\hline $\begin{array}{c}\text { Median age at cancer } \\
\text { diagnosis }\end{array}$ & - & $44-52$ years & 70 years & $\begin{array}{c}\text { Shiels MS, et al. Ann Intern Med } \\
\text { 2010 }\end{array}$ \\
\hline Gender & male & $86 \%$ & $57.8 \%$ & Spano JP et al. Med Oncol 2004 \\
\hline Race & white & no current available data & Kiderlen TR et al. Oncol Res \\
Treat 2017
\end{tabular}

\section{Therapy}

\subsection{Surgery and Radiotherapy}

Surgical resection is a milestone component in the therapeutic algorithm of early and locally advanced stage LC, but its safety is unclear in HIV-infected patients. A comparative cohort study evaluating LC surgical outcomes in HIV-positive patients $(n=22)$ compared to patients with negative or unknown HIV status $(n=2430)$ demonstrated more frequent surgical complications and poorer post-surgical survival [45].

However, there are conflicting data about this topic. Horberg et al. conducted an extensive observational cohort analysis of surgically treated HIV-infected patients $(n=352)$, comparing surgical outcomes and morbidity with those in matched HIV-uninfected patients. Authors did not find a statistically different complication rate between the two groups, except for incidence of postoperative pneumonia and potential 12-month mortality [46].

Moreover, a recent data collection about a national cohort of LC patients showed that surgery is safe in HIV-positive patients $(n=137)$, being surgical complications and 30-day mortality similar to those uninfected ones $(n=8234)$ [47]. Small single institution series of NSCLC patients $(n=6)$ who underwent lobectomy or segmentectomy seems to confirm the feasibility of surgery in HIV-positive patients [48].

There are no prospective data on the efficacy of thoracic radiotherapy in HIV+ patients with locally advanced LC, with available data coming from case-control series and case reports. The potentially higher toxicity risk in PLWH would be turn down with the modern technique of intensity modulated radiotherapy (IMRT) [49]. Thus, in the absence of conclusive data, there is no reason to exclude HIV-positive patients with LC from radiotherapy, when indicated. However, clinicians should pay 
particular attention to the management of radiation treatment side effects, especially in terms of severe esophagitis: this risk might be higher in HIV-positive patients, with CD4+ T cell count and combined HAART regimens as possible causes [49].

A recent case-control study based on Surveillance, Epidemiology, and End Results (SEER) cancer registry dataset investigated whether prognosis of elderly patients ( $\geq 65$ years) affected by early-stage solid cancer is influenced by HIV-infection. PLWH affected by colorectal, breast (BC) or prostate cancer (PC) were found to have a worse outcome, even in terms of cancer-specific mortality for BC and PC, but prognosis for LC resulted not statistically different by HIV status [50].

This supports the trend over the years for a better prognosis of HIV-patients with LC, when treated similarly to those HIV-negative patients.

\subsection{Chemotherapy and Target Therapy}

Anticancer therapy deserves some caution in patients with HIV infection, because of drug-drug interactions (DDIs) and the immunosuppressive nature of the cytotoxic agents [51,52].

Several drugs currently employed in HAART regimens, in particular protease inhibitors (PIs), nucleoside reverse transcriptase inhibitors (NRTIs) and non-nucleoside reverse transcriptase inhibitors (NNRTIs), can cause drug interactions inducing or inhibiting the transporters and cytochrome (CYP) P450 enzymes, such as P-glycoprotein [53]. Indeed, many antineoplastic agents are metabolized by the CYP system, and as a consequence the combination of ART and chemotherapy could result in either a drug accumulation and excess of toxicity or vice versa in a quick drug clearance and impaired activity [51,54].

Among the PIs, ritonavir is a stronger inhibitor of CYP3A activity, while NNRTIs can induce metabolism, reducing the efficacy of antiblastic drugs.

Below we propose some example of DDIs between ART and antiblastic agents used in solid tumor, specifically in LC, in order to avoid cumulative adverse events.

The exposure to and action of antimetabolites such as gemcitabine, antitumor antibiotics and platinum is scarcely influenced by a HAART, because these agents are mainly metabolized though a route different from CYP450 [52]. Meanwhile, DDIs can be expected with alkylating agents, taxanes, vinca alkaloids, epipodophyllotoxins and corticosteroids, often used in cancer patients [55].

Specifically, paclitaxel and docetaxel are CYP2C8 and CYP3A4 substrates and their combined administration with CYP inhibitors causes an altered pharmacokinetics with an associated risk of severe myelosuppression and peripheral neuropathy. Significantly, ritonavir and ketoconazole resulted in an even riskier increase in docetaxel AUC, when administered together [56].

Moreover, vinca alkaloids, such as vincristine, are metabolized by CYP3A4, thus a combination of drugs like ritonavir or other PIs can induce high vinca levels with an increased risk of neurotoxicity, myelosuppression; ritonavir/lopinavir could increase the vincristine adverse event of paralytic ileus [57]. Epipodophyllotoxins are metabolized by the CYP3A4 so that the interaction, for example, of etoposide with a PIs could increase its blood concentration with a high-risk and severity of mucositis, myelosuppression and alteration of transaminases [54].

Platinum-based regimens have no specific interaction with ART, but cisplatin-induced nephrotoxicity may need dosage adjustment for some antiretroviral drugs, in particular for tenofovir [58].

In addition, corticosteroids are often part of premedication in chemotherapy regimens and the interaction with antiretroviral-agents could mediate a modulation of their biotransformation. In particular, dexamethasone and methylprednisolone are both substrates and concentration-dependent inducer of CYP3A4 so their blood levels may decrease the efficacy of NNRTIs and PIs [59].

Even if evidence is based on few experiences, it indicates that PLWH with malignancies should continue HAART during chemotherapy, in order to face the hematologic toxicity, that is the decrease in the number of CD4 lymphocytes and the related complications such as increasing the risk of opportunistic infections. In this regard, the prophylaxis for Pneumocystis jiroveci and other 
opportunistic infections should be administrated in PLWH with cancer when initiating treatment, regardless of CD4+ T-cell count [60].

Furthermore, patients who receive a combination of antineoplastic agents and HAART can achieve better response and survival rates than patients who receive chemotherapy alone [6,55].

Thanks to the progress of both HAART and anticancer therapy, the outcome for PLWH with cancers greatly improved: compared with pre-HAART era, the 5-year overall survival (OS) rate for HIV-infected patients with HL and DLBCL over time has more than doubled [10]; prognosis of patients affected by anal cancer is similar between PLWH and the general population [61]. Despite the modern HAART era, in a study conducted on 71 PLWH and 2463 HIV-uninfected individuals diagnosed with NSCLC, among PLWH OS was significantly worse in PLWH with 5-year OS probability of $9.1 \%$ and $17.9 \%$ for PLWH and HIV-uninfected individuals, respectively $(p<0.01)$ [62].

Even if the incidence of LC harboring EGFR-sensitive mutations is similar in PLWH and in the general population, data about tolerance, response to targeted therapy with tyrosine kinase inhibitors (TKIs) and prognosis are lacking. A case report of 2 HIV-positive patients diagnosed with EGFR mutated LADC showed the promising effectiveness and safety of EGFR-TKIs concomitant with antiretroviral therapy for an extended period [63].

Due to the TKIs' extensive metabolism by CYP3A4, concomitant ART medications can increase their exposure, modifying the metabolism and efficacy of the drug [64]. Moreover, both PIs and TKIs can cause QT prolongation, arrhythmias and sudden death [58].

Experience from two HIV-infected patients with ALK-rearranged NSCLC proved that these patients had good responses to first as well as to second generation ALK-inhibitors, but both patients required a preventive modification of HAART regimens in order to avoid DDIs: ALK-TKIs are metabolized by CYP3A4, so a co-administration of CYP inhibitors can cause QT prolongation [35].

\subsection{Immunotherapy}

Immune response modulation through the use of specific immune check-point inhibitors (ICIs) has revolutionized the treatment of different cancer types in the last years.

One of the most studied mechanism driving tumor immune escape resides in the signaling pathway, involving the programmed death 1 (PD-1) expressed on the surface of activated T cells and its ligand (PD-L1) expressed by tumor cells. Immune checkpoints have become of great importance as a therapeutic target in NSCLC, with several anti PD-1 and anti PD-L1 agents being successfully tested and approved by regulatory drug agencies [65-69].

HIV virus infection in cancer patients may shape and interact with tumor-immune microenvironment (TiME), thus potentially affecting the successful use ICIs [70]. Chronic viral infection and cancer are pathological conditions dominated by chronic inflammation and an insufficient antigen clearance. The consequence is a difficult construction in HIV patients of a functional anti-cancer immune response, with $\mathrm{T}$ cells becoming exhausted for a high acquired expression of different negative check-point receptors [71] (Figure 2).

At this regard, PD-L1 expression and TiME have been investigated even in PLWH affected by LC. HIV status seems not to influence the expression of PD-L1 in NSCLC [72], even if in some case-series HIV-infected patients have found to exhibit a higher PD-L1 expression [73]. Significantly, immune-cell infiltration was found to be higher in HIV tumors, characterized by more CD8+ T cells, B cells and macrophages than in control patients. These findings suggest that PLWH might be equally responsive to ICIs [73].

Moreover, in a small case-control study of 26 LC patients, tumor cells from HIV-positive subjects $(n=13)$ express much more the receptor B7-H3 expression compared to HIV-negative ones $(n=13)$, while tumor PD-L1 expression, as well as PD-1 and PD-L1 expression on tumor infiltrating lymphocytes (TILs) was similar between the two groups [74]. B7-H3 could negatively regulate T-cells activation and tumor-associated macrophages polarization, thus promoting cancer immune escape [75]. 


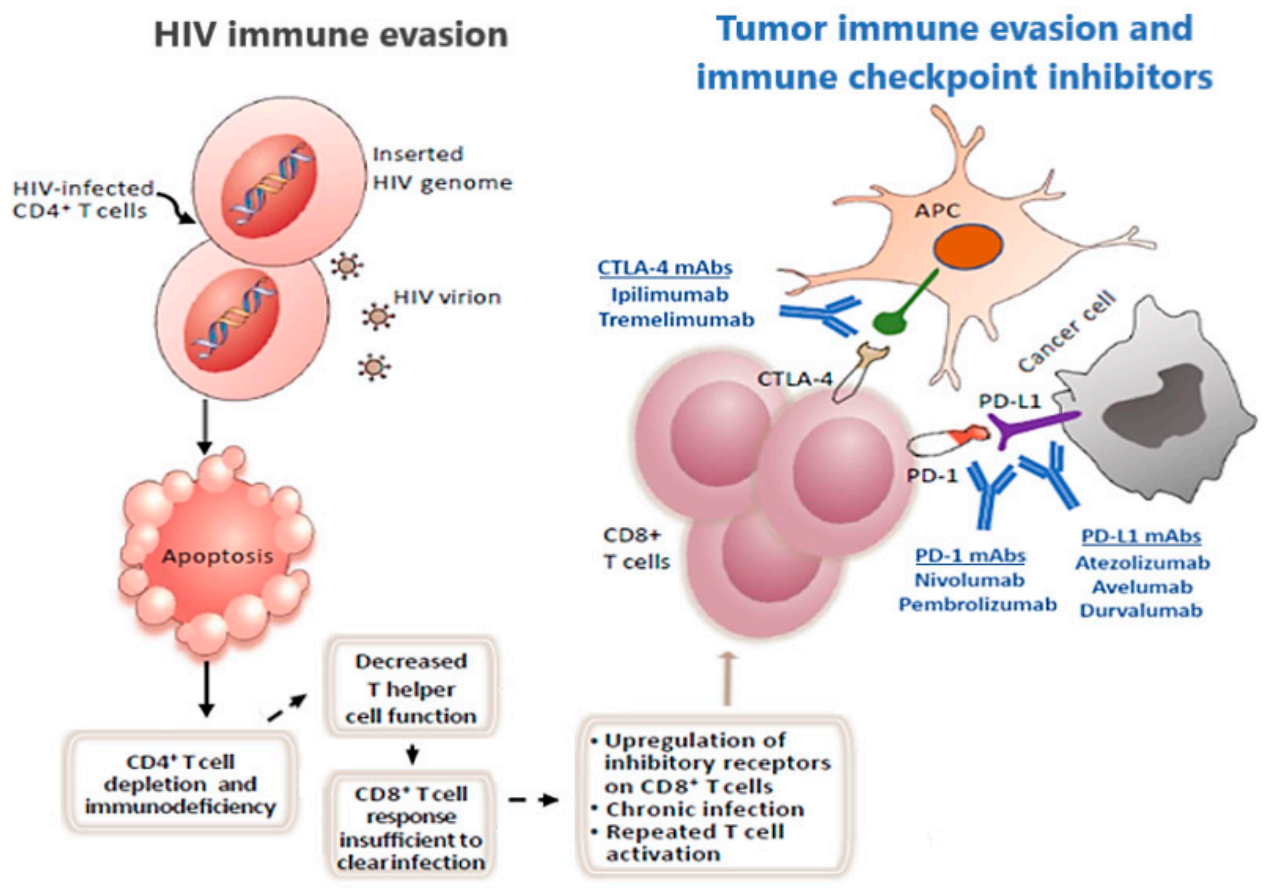

Figure 2. The T cell response to HIV infection, tumor immune evasion in HIV positive patients and immune checkpoint blockade. HIV infection lead both to a depletion and decreased function of CD4+ $\mathrm{T}$ cells. This phenomenon causes an insufficient anticancer cytotoxic $\mathrm{T}$ cell response and CD8+ T cells to upregulate their inhibitory receptors (iRs), thus increasing cancer risk and tumor immune evasion. Immune checkpoint inhibitors aim to revert cancer immune escape, acting on iRs expressed by tumor cell or by CD8+ T cells, thus that the use of these agents may be crucial for HIV infected people with cancer. CTLA-4: Cytotoxic T-Lymphocyte Antigen 4; mAbs: monoclonal antibody; PD-1: programmed cell death protein 1; PD-L1: Programmed death-ligand 1.

No difference in tumor PD-L1 expression status by HIV status was found, also according to another cohort study, that showed how a high PD-L1 level in NSCLC resulted to be a negative prognostic in HIV-positive but not in HIV-negative individuals. Thus possibly, in those HIV patients, the PD-1/PD-L1 interaction exerts an immune suppressive action more pronounced than in HIV-uninfected ones [76].

The efficacy of PD-1/PD-L1 blockade therapy will likely depend on the potency of cytotoxic effect of CTLs. CTLs response in PLWH is characterized by severe exhausted CD8+ due to persistent immune stimulation by HIV [77], so that antitumor activity of CTLs might be weak even after blockade of the PD-1/PD-L1 pathway.

Anyhow, recent analyses showed preliminarily a reactive TiME that characterize NSCLC from HIV-positive patients immune-reactive microenvironment in HIV-associated NSCLC [73,78].

A recent review involving patients $(n=73)$ treated with ICIs targeting PD-1/PD-L1 axis and/or CTLA-4 showed that ICIs seem safe and active in HIV-positive patients suffering from advanced solid cancer [79].

Evidence on this issue comes also from results of the first prospective study, a phase I trial evaluating the safety profile of pembrolizumab ( $200 \mathrm{mg} \mathrm{q} 3 \mathrm{w}$ for up to 35 doses) with continued ART in 30 HIV-positive patients affected by metastatic or locally advanced cancer, including one NSCLC patient. The study showed that this anti PD-1 agent is safe in PLWH in terms of rate and grade of adverse event, comprising immune-related events of clinical interest (irECI), similar for frequency to those occurring in HIV-negative patients treated with the same drug inside pivotal trials. Pembrolizumab did not significantly interfere with ART efficacy, nor in terms of T helper count nor HIV-virus replication control [80].

Waiting for results from other currently ongoing prospective trials of ICIs in this special patient population, some suggestions about this topic come from experience with lower level of evidence. 
According to a small retrospective study $(n=17)$, anti PD-1 and anti PD-L1 appeared safe with no detrimental effect on HIV-infection control to treat PLWH with advanced solid tumor, including also NSCLC histology $(n=10)$ [81].

Confirmation in this sense came from another real-life experience from a series of PLWH cancer patients, of whom 21 were affected by NSCLC. The efficacy and safety of anti-PD1 agents nivolumab and pembrolizumab was demonstrated, and no negative effect of immunotherapy on Thelper count and/or HIV-viral load was registered [82].

Others small series and case reports highlighted and confirmed that ICIs are safe and active in NSCLC from HIV-positive patients [83-85].

Ad-hoc designed clinical trials testing ICIs in cancer patients with HIV-infection are needed to validate the above findings.

\section{Perspectives}

Regardless of immune status, PLWH are in any case much more predisposed to develop cancers because of relevant presence of carcinogenic stimuli, even in terms of frequent co-viral infections, such as high-risk human papillomavirus (hrHPV) and HBV/HCV.

Preventing smoking may potentially avoid near a quarter of NADC in PLWH, according to a wide collaboration of cohort studies [86].

Morbidity and mortality for cancer could be lowered in HIV-positive people, like in the rest of the population, by the adoption of a screening procedure [87]. This might be true also for LC in PLWH, who generally smoke more and tend to quit smoking less than the HIV-negative adulthood counterpart [88].

Based on results from a national screening trial, the U.S. Preventive Services Task Force suggested to screen yearly heavy smokers older than 55 years with a low-dose computed tomography (LD-CT) [88,89].

Recognized thresholds in this specific case were 30-pack years, but maybe could be lowered in people with a history of immunodeficiency. It is unknown whether susceptibility to smoke induced DNA-damage is higher in HIV-positive people rather than in those HIV-negative, but certainly smoke and HIV exert a cooperative inflammatory and immunosuppressive action [17]. A French trial, conducted in PLWH with a nadir T-helper less than 350 cells/mL, showed that a single round LD-CT is able to early detect LC in patients older than 40 years and with at least 20-pack years [90].

Waiting for results from other studies, it would be advisable to offer LC screening to high-risk patients, rather than to all PLWH globally considered. The possible LD-CT false positive findings in HIV-positive patients could in fact be substantial, due to their higher risk of pulmonary infections by different germs (bacteria, mycobacterium, fungi). To combine radiomics with clinical-radiological features may be helpful in identifying those opportunistic pulmonary infections (OPIs) that mimic LC in HIV-infected patients [91].

HIV infection and/or AIDS condition are common exclusion criteria of most cancer clinical studies [92]. The scientific community has to review this aspect, widening the access to trials to those long-marginalized patient categories [93]. Evidence-based medicine is necessary to refine the therapeutic algorithm for PLWH suffering from malignancies; to date, the therapeutic approach has derived from that usually used for HIV-negative patients, but it is conceptually a mistake, because some characteristics may potentially differ based on HIV-status.

No ad-hoc approved and shared guidelines exist to treat PLWH having cancer, and this is quite destabilizing for healthcare providers, therefore find themselves dealing with bias in their approach to the HIV-positive cancer patient [94].

In the recent past, PLWH with cancer have been undertreated with a subsequent negative impact on their prognosis, but no excess in toxicity of antineoplastic agents in HIV-infected patients has shown to date. The best oncologic treatment available should be offered to these patients, taking into account possible DDIs and CD4+ counts. A better global health policy awareness, as well as clinicians' sensitization and cooperation are fundamental to guarantee a wider access to cancer therapies. 
Anyhow, for some cancers, HIV-infected patients live less than those HIV-uninfected, even after adjusting for administered cancer treatments [50]. Despite PLWH with NSCLC, when treated with the best HAART, could have a comparable cancer mortality compared to the general population, they have a significantly higher all-cause mortality: further investigations are needed to understand the reasons of this phenomena, and how HIV worsen mortality in people with cancer and other comorbidities [62].

Clinical trials analyzing the impact of HIV infection on cancer and cancer treatment are urgently warranted, and results of on-going trials will possibly contribute to expanding knowledge on this largely unexplored health issue (Table 2).

Table 2. Clinical trials investigating HIV and lung cancer. The table listed clinical studies investigating the impact of HIV infection on risk factors, epidemiology, features of LC, as well as implication for LC treatments. Information of active/closed clinical trials has been derived from https://clinicaltrials.gov. The three trials marked in light blue enroll/enrolled people with cancer HIV-uninfected or PLWH without cancer, but anyhow the contribute from these trials might be important to acquire more information about DDIs. ${ }^{* *}$ when available. ART: antiretroviral therapy; ChT: chemotherapy; DCR: disease control rate; HL: Hodgkin Lymphoma; ICIs: Immunological Checkpoint Inhibitors; LC: lung cancer; MTD: maximum tolerated dose; NGS: next-generation sequencing; NSCLC: non-small cell lung cancer; ORR: objective response rate; pts: patients; PS: performance status; pts: patients.

\begin{tabular}{|c|c|c|c|c|}
\hline $\begin{array}{c}\text { Trial NCT } \\
\text { (Acronimus) }\end{array}$ & Drug Tested & Trial Title & Endpoint and Results** & Status \\
\hline $\begin{array}{l}01296113 \\
\text { (CHIVA) }\end{array}$ & $\begin{array}{l}\text { Carboplatin plus } \\
\text { pemetrexed }\end{array}$ & $\begin{array}{c}\text { Chemotherapy for LC in HIV+ } \\
\text { pts with advanced } \\
\text { non-squamous NSCLC }\end{array}$ & $\begin{array}{l}\text { DCR after } 4 \text { cycles of } \\
\text { carboplatin plus } \\
\text { pemetrexed }\end{array}$ & $\begin{array}{c}\text { Completed } \\
\text { No results posted }\end{array}$ \\
\hline 00276588 & $\begin{array}{l}\text { Gemcitabine plus } \\
\text { carboplatin } \\
\text { followed by } \\
\text { paclitaxel }\end{array}$ & $\begin{array}{l}\text { Gemcitabine and carboplatin } \\
\text { followed by paclitaxel in pts } \\
\text { with PS = } 2,3 \text { or other } \\
\text { significant co-morbidity (HIV } \\
\text { or s/p organ transplantation) } \\
\text { in advanced NSCLC }\end{array}$ & $\begin{array}{l}\text { Sequential ChT is well } \\
\text { tolerated and active. } \\
\text { The survival is comparable } \\
\text { to that of other regimens } \\
\text { utilized in PS = } 2 \text { pts with } \\
\text { superior tolerability. The } \\
\text { prognosis for these pts is } \\
\text { very poor even with } \\
\text { treatment }\end{array}$ & $\begin{array}{c}\text { Completed } \\
\text { Results posted }\end{array}$ \\
\hline 02134886 & Erlotinib & $\begin{array}{l}\text { Erlotinib Hydrochloride in } \\
\text { treating NSCLC that is } \\
\text { metastatic or cannot be } \\
\text { removed by surgery in pts } \\
\text { with HIV }\end{array}$ & $\begin{array}{l}\text { Safety, tolerability and } \\
\text { MTD of erlotinib in } \\
\text { combination with ART }\end{array}$ & $\begin{array}{c}\text { Terminated } \\
\text { (Poor enrolment) }\end{array}$ \\
\hline 01822522 & Cabozantinib & $\begin{array}{l}\text { Cabozantinib S-Malate in } \\
\text { treating pts with advanced } \\
\text { solid tumors and HIV }\end{array}$ & $\begin{array}{l}\text { Safety, tolerability and } \\
\text { MTD of cabozantinib }\end{array}$ & Recruiting \\
\hline $\begin{array}{c}03304093 \\
\text { (CHIVA2) }\end{array}$ & Nivolumab & $\begin{array}{l}\text { Immunotherapy by } \\
\text { nivolumab for HIV+ pts with } \\
\text { advanced NSCLC }\end{array}$ & DCR & Recruiting \\
\hline $\begin{array}{c}03767465 \\
(\text { PembroHIV) }\end{array}$ & ICI & $\begin{array}{l}\text { Treatment with ICIs of } \\
\text { HIV-infected subjects with } \\
\text { cancer (advanced melanoma } \\
\text { or other cancers in which the } \\
\text { use of ICIs is clinically } \\
\text { indicated) }\end{array}$ & $\begin{array}{l}\text { Changes in HIV-viral load } \\
\text { and immune-phenotype of } \\
\text { cellular populations }\end{array}$ & $\begin{array}{c}\text { Completed } \\
\text { No results posted }\end{array}$ \\
\hline 02408861 & $\begin{array}{l}\text { Ipilimumab plus } \\
\text { nivolumab }\end{array}$ & $\begin{array}{l}\text { Nivolumab and ipilimumab in } \\
\text { treating pts with HIV } \\
\text { associated relapsed or } \\
\text { refractory classical HL or solid } \\
\text { tumors (comprising LC) that } \\
\text { are metastatic or cannot be } \\
\text { removed by surgery }\end{array}$ & $\begin{array}{c}\text { MTD of nivolumab, ORR, } \\
\text { immune function, change } \\
\text { in immune status/HIV } \\
\text { viral load }\end{array}$ & Recruiting \\
\hline 00791336 & $\begin{array}{l}\text { Nelfinavir with RT } \\
\text { and ChT }\end{array}$ & $\begin{array}{c}\text { Study to evaluate using } \\
\text { nelfinavir with } \\
\text { chemoradiation for NSCLC }\end{array}$ & PCR & $\begin{array}{c}\text { Terminated } \\
\text { (Poor enrolment) }\end{array}$ \\
\hline
\end{tabular}


Table 2. Cont.

\begin{tabular}{|c|c|c|c|c|}
\hline $\begin{array}{c}\text { Trial NCT } \\
\text { (Acronimus) }\end{array}$ & Drug Tested & Trial Title & Endpoint and Results** & Status \\
\hline 01249443 & $\begin{array}{l}\text { Paclitaxel plus } \\
\text { carboplatin }\end{array}$ & $\begin{array}{l}\text { Paclitaxel and carboplatin in } \\
\text { treating pts with metastatic or } \\
\text { recurrent solid tumors } \\
\text { (comprising NSCLC) and HIV }\end{array}$ & $\begin{array}{l}\text { - Safety, tolerability of } \\
\text { vorinostat in combination } \\
\text { with ChT. } \\
\text { - MTD of the combination }\end{array}$ & $\begin{array}{c}\text { Terminated } \\
\text { (Inadequate accrual } \\
\text { rate) } \\
\text { No results posted }\end{array}$ \\
\hline 01567722 & - & $\begin{array}{l}\text { Collecting and studying tissue } \\
\text { samples from pts with } \\
\text { HIV-Associated Malignancies } \\
\text { (diffuse large B-cell } \\
\text { lymphomas, LC, anal cancer } \\
\text { and cervical cancer) }\end{array}$ & $\begin{array}{l}\text { - To obtain high-quality } \\
\text { tissue from pts with HIV-1 } \\
\text { malignancy } \\
\text { - To study clinical, genetic, } \\
\text { and immunologic } \\
\text { parameters with } \\
\text { prognostic significance } \\
\text { and/or involved in the } \\
\text { initiation/progression of } \\
\text { HIV-1 malignancies, } \\
\text { including complete NGS } \\
\text { of HIV-associated cancers }\end{array}$ & Recruiting \\
\hline $\begin{array}{c}01748136 \\
\text { (NA_00036809) }\end{array}$ & - & $\begin{array}{l}\text { Screening for LC in the HIV } \\
\text { pts }\end{array}$ & $\begin{array}{l}\text { Differences in stage } \\
\text { distribution of } \\
\text { HIV-seropositive pts at LC } \\
\text { diagnosis between those } \\
\text { who are screened by spiral } \\
\text { CT and historic controls }\end{array}$ & $\begin{array}{l}\text { Completed } \\
\text { No results posted }\end{array}$ \\
\hline $\begin{array}{c}01207986 \\
(\text { EP48 HIV } \\
\text { CHEST })\end{array}$ & - & $\begin{array}{c}\text { Early LC diagnosis in HIV } \\
\text { infected population with an } \\
\text { important smoking history } \\
\text { with low dose CT: a pilot } \\
\text { study }\end{array}$ & $\begin{array}{l}\text { Prevalence of LC detected } \\
\text { by low-dose CT scan }\end{array}$ & $\begin{array}{l}\text { Completed } \\
\text { No results posted }\end{array}$ \\
\hline 00491335 & - & $\begin{array}{l}\text { HIV infection and tobacco use } \\
\text { among injection drug users in } \\
\text { Baltimore, Maryland: a pilot } \\
\text { study of biomarkers }\end{array}$ & $\begin{array}{l}\text { - To characterize smoking } \\
\text { habits and compare } \\
\text { tobacco use among } \\
\text { HIV-infected and } \\
\text { uninfected drug users } \\
\text { - To compare serum } \\
\text { nicotine levels and } \\
\text { spirometry results, as a } \\
\text { marker of tobacco use and } \\
\text { a marker of damage to } \\
\text { lung function, respectively }\end{array}$ & $\begin{array}{l}\text { Completed } \\
\text { No results posted }\end{array}$ \\
\hline $\begin{array}{c}01447589 \\
\text { (NelfLung) }\end{array}$ & $\begin{array}{l}\text { Nelfinavir plus } \\
\text { radical } \\
\text { radiotherapy }\end{array}$ & $\begin{array}{l}\text { Radical lung radiotherapy } \\
\text { plus nelfinavir }\end{array}$ & MTD of nelfinavir & $\begin{array}{l}\text { Withdrawn } \\
\text { (poor enrolment) }\end{array}$ \\
\hline 00589056 & $\begin{array}{l}\text { Nelfinavir with RT } \\
\text { and ChT }\end{array}$ & $\begin{array}{l}\text { Nelfinavir, RT, cisplatin and } \\
\text { etoposide in treating } \\
\text { (HIV-uninfected) pts with } \\
\text { stage III NSCLC that cannot be } \\
\text { removed by surgery }\end{array}$ & $\begin{array}{c}\text { Nelfinavir administered } \\
\text { with concurrent ChT-RT is } \\
\text { associated with acceptable } \\
\text { toxic effects and a } \\
\text { promising ORR, local } \\
\text { failure, PFS and OS in } \\
\text { unresectable NSCLC }\end{array}$ & Completed \\
\hline 03367754 & Pembrolizumab & $\begin{array}{c}\text { A single dose of } \\
\text { pembrolizumab in } \\
\text { HIV-infected people }\end{array}$ & $\begin{array}{l}\text { Safety of pembrolizumab } \\
\text { in PLWH who have a low } \\
\text { CD4+ T cell count despite } \\
\text { taking medicines that } \\
\text { control HIV replication }\end{array}$ & Recruiting \\
\hline 02595866 & Pembrolizumab & $\begin{array}{l}\text { Pembrolizumab in pts with } \\
\text { HIV and relapsed/refractory or } \\
\text { disseminated malignant } \\
\text { neoplasm (comprising } \\
\text { NSCLC) }\end{array}$ & $\begin{array}{c}\text { - Frequency of observed } \\
\text { AEs } \\
\text { - Incidence of } \\
\text { immune-related AEs of } \\
\text { clinical interest } \\
\text { - Incidence of cART-related } \\
\text { AEs }\end{array}$ & Recruiting \\
\hline
\end{tabular}


Table 2. Cont.

\begin{tabular}{cccc}
\hline $\begin{array}{c}\text { Trial NCT } \\
\text { (Acronimus) }\end{array}$ & Drug Tested & Trial Title & Endpoint and Results** \\
\hline 03858491 & Osimertinib & $\begin{array}{c}\text { Pharmacokinetic Boosting of } \\
\text { Osimertinib in pts with } \\
\text { EGFR-mutated NSCLC }\end{array}$ & $\begin{array}{c}\text { Evaluate if systemic } \\
\text { exposure of osimertinib is } \\
\text { increased when it is } \\
\text { co-administered with } \\
\text { aPti-HIV drug cobicistat }\end{array}$ \\
\hline 03706625 & $\begin{array}{c}\text { Integrated discovery of new } \\
\text { immuno-molecular actionable } \\
\text { biomarkers for tumors with } \\
\text { immune-suppressed } \\
\text { environment }\end{array}$ & $\begin{array}{c}\text { Analyse tumor biomarkers } \\
\text { on frozen biopsy for three } \\
\text { types of cancer (non-HL, } \\
\text { LC and glioma) }\end{array}$ & Not yet recruiting \\
\hline
\end{tabular}

Author Contributions: Conceptualization, writing—original draft preparation by S.F. and A.F.; review and editing by L.B., V.G., P.C. and G.P. All authors have read and agreed to the published version of the manuscript.

Funding: This research received no external funding.

Acknowledgments: No acknowledge to declare.

Conflicts of Interest: The authors declare no conflict of interest.

\section{References}

1. Global HIV \& AIDS Statistics-2019 Fact Sheet/UNAIDS. Available online: https://www.unaids.org/en/ resources/fact-sheet (accessed on 10 October 2019).

2. Lee, J.Y.; Dhakal, I.; Casper, C.; Noy, A.; Palefsky, J.M.; Haigentz, M.; Krown, S.E.; Ambinder, R.F.; Mitsuyasu, R.T. Risk of Cancer among Commercially Insured HIV-Infected Adults on Antiretroviral Therapy. J. Cancer Epidemiol. 2016, 2016, 2138259. [CrossRef]

3. Grulich, A.E.; van Leeuwen, M.T.; Falster, M.O.; Vajdic, C.M. Incidence of cancers in people with HIV/AIDS compared with immunosuppressed transplant recipients: A meta-analysis. Lancet 2007, 370, 59-67. [CrossRef]

4. Impact of the Expanded AIDS Surveillance Case Definition on AIDS Case Reporting-United States, First Quarter, 1993. Available online: https://www.cdc.gov/mmwr/preview/mmwrhtml/00020374.htm (accessed on 14 July 2019).

5. Siegfried, N.; Uthman, O.A.; Rutherford, G.W. Optimal time for initiation of antiretroviral therapy in asymptomatic, HIV-infected, treatment-naive adults. Cochrane Database Syst. Rev. 2010, 17, CD008272.

6. Rubinstein, P.G.; Aboulafia, D.M.; Zloza, A. Malignancies in HIV/AIDS: From epidemiology to therapeutic challenges. AIDS 2014, 28, 453-465. [CrossRef] [PubMed]

7. Shiels, M.S.; Pfeiffer, R.M.; Hall, H.I.; Li, J.; Goedert, J.J.; Morton, L.M.; Hartge, P.; Engels, E.A. Proportions of Kaposi Sarcoma, Selected Non-Hodgkin Lymphomas, and Cervical Cancer in the United States Occurring in Persons With AIDS, 1980-2007. JAMA 2011, 305, 1450. [CrossRef] [PubMed]

8. Meredith, S.; Engels, E. Evolving epidemiology of HIV-associated malignancies. Curr. Opin. HIV AIDS 2017, 25, 1032-1057.

9. Yarchoan, R.; Uldrick, T.S. HIV-Associated Cancers and Related Diseases. N. Engl. J. Med. 2018, 378, 1029-1041. [CrossRef]

10. Ji, Y.; Lu, H. Malignancies in HIV-Infected and AIDS patients. Adv. Exp. Med. Biol. 2017, 1018, $167-179$.

11. Shiels, M.; Islam, J.; Rosenberg, P.; Hall, H.; Jacobson, E.; Engels, E. Projected Cancer Incidence Rates and Burden of Incident Cancer Cases in HIV-Infected Adults in the United States Through 2030. Ann. Intern. Med. 2019, 168, 866-873. [CrossRef]

12. Sigel, K.; Makinson, A.; Thaler, J. Lung cancer in persons with HIV. Curr. Opin. HIV AIDS 2017, 12, 31-38. [CrossRef]

13. Shiels, M.S.; Cole, S.R.; Kirk, G.D.; Poole, C. A meta-analysis of the incidence of non-AIDS cancers in HIV-infected individuals. J. Acquir. Immune Defic. Syndr. 2009, 52, 611-622. [CrossRef] [PubMed]

14. Bearz, A.; Vaccher, E.; Talamini, R.; Berretta, M.; Tirelli, U. Comment on 'Lung cancer in the Swiss HIV Cohort Study: Role of smoking, immunodeficiency and pulmonary infection'. Br. J. Cancer 2012, 106, 1899-1900. [CrossRef] [PubMed] 
15. Mdodo, R.; Frazier, E.L.; Dube, S.R.; Mattson, C.L.; Sutton, M.Y.; Brooks, J.T.; Skarbinski, J. Cigarette Smoking Prevalence Among Adults With HIV Compared With the General Adult Population in the United States. Ann. Intern. Med. 2015, 162, 335. [CrossRef]

16. Sigel, K.; Wisnivesky, J.; Gordon, K.; Dubrow, R.; Justice, A.; Brown, S.T.; Goulet, J.; Butt, A.A.; Crystal, S.; Rimland, D.; et al. HIV as an independent risk factor for incident lung cancer. AIDS 2012, 26, 1017-1025. [CrossRef]

17. Rossouw, T.M.; Anderson, R.; Feldman, C. Impact of HIV infection and smoking on lung immunity and related disorders. Eur. Respir. J. 2015, 46, 1781-1795. [CrossRef] [PubMed]

18. Engels, E.A.; Brock, M.V.; Chen, J.; Hooker, C.M.; Gillison, M.; Moore, R.D. Elevated Incidence of Lung Cancer Among HIV-Infected Individuals. J. Clin. Oncol. 2006, 24, 1383-1388. [CrossRef]

19. Serrão, R.; Piñero, C.; Velez, J.; Coutinho, D.; Maltez, F.; Lino, S.; Sarmento, E.; Castro, R.; Tavares, A.P.; Pacheco, P.; et al. Non-AIDS-related comorbidities in people living with HIV-1 aged 50 years and older: The AGING POSITIVE study. Int. J. Infect. Dis. 2019, 79, 94-100. [CrossRef]

20. Kirk, G.D.; Merlo, C.; O’Driscoll, P.; Mehta, S.H.; Galai, N.; Vlahov, D.; Samet, J.; Engels, E.A. HIV Infection Is Associated with an Increased Risk for Lung Cancer, Independent of Smoking. Clin. Infect. Dis. 2007, 45, 103-110. [CrossRef]

21. Helleberg, M.; May, M.T.; Ingle, S.M.; Dabis, F.; Reiss, P.; Fätkenheuer, G.; Costagliola, D.; d'Arminio, A.; Cavassini, M.; Smith, C.; et al. Smoking and life expectancy among HIV-infected individuals on antiretroviral therapy in Europe and North America. AIDS 2015, 29, 221-229. [CrossRef]

22. Lambert, A.A.; Merlo, C.A.; Kirk, G.D. Human Immunodeficiency Virus-Associated Lung Malignancies. Clin. Chest Med. 2013, 34, 255-272. [CrossRef]

23. Winstone, T.A.; Man, S.F.P.; Hull, M.; Montaner, J.S.; Sin, D.D. Epidemic of Lung Cancer in Patients With HIV Infection. Chest 2013, 143, 305-314. [CrossRef] [PubMed]

24. Althoff, K.N.; McGinnis, K.A.; Wyatt, C.M.; Freiberg, W.M.; Gilbert, C.; Oursler, K.K.; Rimland, D.; Rodriguez-Barradas, R.D.; Park, L.S.; Skanderson, M.; et al. Comparison of Risk and Age at Diagnosis of Myocardial Infarction, End-Stage Renal Disease, and Non-AIDS-Defining Cancer in HIV-Infected Versus Uninfected Adults. Clin. Infect Dis. 2015, 60, 627-638. [CrossRef] [PubMed]

25. Burgi, A.; Brodine, S.; Wegner, S.; Milazzo, K.; Wallace, M.R.; Spooner, K.; Blazes, D.L.; Agan, B.K. Incidence and risk factors for the occurrence of non-AIDS-defining cancers among human immunodeficiency virus-infected individuals. Cancer 2005, 104, 1505-1511. [CrossRef]

26. Powles, T.; Robinson, D.; Stebbing, J.; Shamash, J.; Nelson, M.; Gazzard, B.; Mandelia, S.; Moller, H.; Bower, M. Highly Active Antiretroviral Therapy and the Incidence of Non-AIDS-Defining Cancers in People With HIV Infection. J. Clin. Oncol. 2009, 27, 884-890. [CrossRef] [PubMed]

27. Kowalska, J.D.; Reekie, J.; Mocroft, A.; Reiss, P.; Ledergerber, B.; Gatell, J.; d'Arminio Monforte, A.; Phillips, A.; Lundgren, J.D.; Kirk, O.; et al. Long-term exposure to combination antiretroviral therapy and risk of death from specific causes. AIDS 2012, 26, 315-323. [CrossRef] [PubMed]

28. Mani, D.; Haigentz, M.; Aboulafia, D.M. Lung Cancer in HIV Infection. Clin. Lung Cancer 2012, 13, 6-13. [CrossRef]

29. Sridhar, K.; Flores, M.; Raub, W.; Saldana, M. Lung Cancer in Patients with Human Immunodeficiency Virus Infection Compared with Historic Control Subjects. Chest 2019, 102, 1704-1708. [CrossRef]

30. Tirelli, U.; Spina, M.; Sandri, S.; Serraino, D.; Gobitti, C.; Fasan, M.; Sinicco, A.; Garavelli, P.; Ridolfo, A.L.; Vaccher, E. Lung carcinoma in 36 patients with human immunodeficiency virus infection. Cancer 2000, 88, 563-569. [CrossRef]

31. Brock, M.V.; Hooker, C.M.; Engels, E.A.; Moore, R.D.; Gillison, M.L.; Alberg, A.J.; Keruly, J.C.; Yang, S.C.; Heitmiller, R.F.; Baylin, S.B.; et al. Delayed diagnosis and elevated mortality in an urban population with HIV and lung cancer: Implications for patient care. J. Acquir. Immune Defic. Syndr. 2006, 43, 47-55. [CrossRef]

32. Marcus, J.L.; Chao, C.; Leyden, W.A.; Xu, L.; Yu, J.; Horberg, M.A.; Klein, D.; Towner, W.J.; Quesenberry, C.P.; Abrams, D.I.; et al. Survival among HIV-infected and HIV-uninfected individuals with common non-AIDS-defining cancers. Cancer Epidemiol. Biomark. Prev. 2015, 24, 1167-1173. [CrossRef]

33. Kiderlen, T.R.; Siehl, J.; Hentrich, M. HIV-associated lung cancer. Oncol. Res. Treat. 2017, 40, 88-92. [CrossRef] [PubMed] 
34. Thaler, J.; Sigel, C.; Beasley, M.B.; Wisnivesky, J.; Crothers, K.; Bauml, J.; Hysell, K.; Emu, B.; Borsu, L.; Sigel, K. Clinically significant mutations in HIV-infected patients with lung adenocarcinoma. Br. J. Cancer 2017, 117, 1392-1395. [CrossRef] [PubMed]

35. Pichardo, R.; Go, R.F.; Qu, L.; Hussein, L.; Gupta, S. HIV-associated Non-small-cell Lung Cancer with Rearrangement of the Anaplastic Lymphoma Kinase Gene: A Report of Two Patients. Cureus 2019, 11, 1-5. [CrossRef] [PubMed]

36. Zheng, J.; Wang, L.; Cheng, Z.; Pei, Z.; Zhang, Z.; Li, Z.; Zhang, X.; Yan, D.; Xia, Q.; Feng, Y.; et al. Molecular Changes of Lung Malignancy in HIV Infection. Sci. Rep. 2018, 8, 13128. [CrossRef] [PubMed]

37. Micalizzi, D.S.; Christensen, K.L.; Jedlicka, P.; Coletta, R.D.; Barón, A.E.; Harrell, J.C.; Horwitz, K.B.; Billheimer, D.; Heichman, K.A.; Welm, A.L.; et al. The Six1 homeoprotein induces human mammary carcinoma cells to undergo epithelial-mesenchymal transition and metastasis in mice through increasing TGF-beta signaling. J. Clin. Investig. 2009, 119, 2678-2690. [CrossRef] [PubMed]

38. Karim, B.O.; Rhee, K.-J.; Liu, G.; Yun, K.; Brant, S.R. Prom1 function in development, intestinal inflammation, and intestinal tumorigenesis. Front. Oncol. 2014, 4, 323. [CrossRef] [PubMed]

39. Santerre, M.; Chatila, W.; Wang, Y.; Mukerjee, R.; Sawaya, B.E. HIV-1 Nef promotes cell proliferation and microRNA dysregulation in lung cells. Cell Cycle 2019, 18, 130-142. [CrossRef]

40. Coghill, A.E.; Shiels, M.S.; Suneja, G.; Engels, E.A. Elevated Cancer-Specific Mortality Among HIV-Infected Patients in the United States. J. Clin. Oncol. 2015, 33, 2376-2383. [CrossRef]

41. Sigel, K.; Crothers, K.; Dubrow, R.; Krauskopf, K.; Jao, J.; Sigel, C.; Moskowitz, A.; Wisnivesky, J. Prognosis in HIV-infected patients with non-small cell lung cancer. Br. J. Cancer 2013, 109, 1974-1980. [CrossRef]

42. Shiels, M.S.; Cole, S.R.; Mehta, S.H.; Kirk, G.D. Lung cancer incidence and mortality among HIV-infected and HIV-uninfected injection drug users. J. Acquir. Immune Defic. Syndr. 2010, 55, 510-515. [CrossRef]

43. Wang, Y.H.; Di Shen, X. Human immunodeficiency virus infection and mortality risk among lung cancer patients. Medcine 2018, 97, e0361. [CrossRef] [PubMed]

44. Suneja, G.; Lin, C.C.; Simard, E.P.; Han, X.; Engels, E.A.; Jemal, A. Disparities in cancer treatment among patients infected with the human immunodeficiency virus. Cancer 2016, 122, 2399-2407. [CrossRef] [PubMed]

45. Hooker, C.M.; Meguid, R.A.; Hulbert, A.; Taylor, J.T.; Shin, J.; Wrangle, J.; Rodgers, K.; Lee, B.; Laskshmanan, S.; Brown, T.; et al. Human immunodeficiency virus infection as a prognostic factor in surgical patients with non-small cell lung cancer. Ann. Thorac. Surg. 2012, 93, 405-412. [CrossRef] [PubMed]

46. Horberg, M.A.; Hurley, L.B.; Klein, D.B.; Follansbee, S.E.; Quesenberry, C.; Flamm, J.A.; Green, G.M.; Luu, T. Surgical outcomes in human immunodeficiency virus-infected patients in the era of highly active antiretroviral therapy. Arch. Surg. 2006, 141, 1238-1245. [CrossRef]

47. Sigel, K.M.; Stone, K.; Wisnivesky, J.P.; Park, L.S.; Kong, C.Y.; Silverberg, M.J.; Brown, S.; Goetz, M.; Rodriguez-Barradas, M.C.; Gibert, C.; et al. Short-term outcomes for lung cancer resection surgery in HIV infection. AIDS 2019, 33, 1353-1360. [CrossRef]

48. Asakawa, A.; Horio, H.; Yamamichi, T.; Okui, M.; Harada, M. Clinical features of HIV-infected patients with non-small-cell lung cancer after lung resection. Gen. Thorac. Cardiovasc. Surg. 2019, 68, 38-42. [CrossRef]

49. Alongi, F.; Giaj-Levra, N.; Sciascia, S.; Fozza, A.; Fersino, S.; Fiorentino, A.; Mazzola, R.; Ricchetti, F.; Buglione, M.; Buonfrate, D.; et al. Radiotherapy in patients with HIV: Current issues and review of the literature. Lancet Oncol. 2017, 18, e379-e393. [CrossRef]

50. Coghill, A.E.; Suneja, G.; Rositch, A.F.; Shiels, M.S.; Engels, E.A. HIV Infection, Cancer Treatment Regimens, and Cancer Outcomes Among Elderly Adults in the United States. JAMA Oncol. 2019. [CrossRef]

51. Mounier, N.; Katlama, C.; Costagliola, D.; Chichmanian, R.M.; Spano, J.P. Drug interactions between antineoplastic and antiretroviral therapies: Implications and management for clinical practice. Crit. Rev. Oncol. Hematol. 2009, 72, 10-20. [CrossRef]

52. Torres, H.A.; Mulanovich, V. Management of HIV infection in patients with cancer receiving chemotherapy. Clin. Infect. Dis. 2014, 59, 106-114. [CrossRef]

53. Flepisi, B.T.; Bouic, P.; Sissolak, G.; Rosenkranz, B. Drug-drug interactions in HIV positive cancer patients. Biomed. Pharmacother. 2014, 68, 665-677. [CrossRef] [PubMed]

54. Beumer, J.H.; Venkataramanan, R.; Rudek, M.A. Pharmacotherapy in cancer patients with HIV/AIDS. Clin. Pharmacol. Ther. 2014, 95, 370-372. [CrossRef] [PubMed] 
55. Berretta, M.; Caraglia, M.; Martellotta, F.; Zappavigna, S.; Lombardi, A.; Fierro, C.; Atripaldi, L.; Muto, T.; Valente, D.; De Paoli, P.; et al. Drug-drug interactions based on pharmacogenetic profile between highly active antiretroviral therapy and antiblastic chemotherapy in cancer patients with HIV infection. Front. Pharmacol. 2016, 7, 71. [CrossRef] [PubMed]

56. Rudek, M.A.; Chang, C.Y.; Steadman, K.; Johnson, M.D.; Desai, N.; Deeken, J.F. Combination antiretroviral therapy (cART) component ritonavir significantly alters docetaxel exposure. Cancer Chemother. Pharmacol. 2014, 73, 729-736. [CrossRef] [PubMed]

57. Levêque, D.; Santucci, R.; Pavillet, J.; Herbrecht, R.; Bergerat, J.P. Paralytic ileus possibly associated with interaction between ritonavir/lopinavir and vincristine. Pharm. World Sci. 2009, 31, 619-621. [CrossRef] [PubMed]

58. Rudek, M.A.; Flexner, C.; Ambinder, R.F. Use of antineoplastic agents in patients with cancer who have HIV/AIDS. Lancet Oncol. 2011, 12, 905-912. [CrossRef]

59. Antoniou, T.; Tseng, A.L. Interactions between antiretrovirals and antineoplastic drug therapy. Clin. Pharmacokinet. 2005, 44, 111-145. [CrossRef]

60. Alfa-Wali, M.; Allen-Mersh, T.; Antoniou, A.; Tait, D.; Newsom-Davis, T.; Gazzard, B.; Nelson, M.; Bower, M. Chemoradiotherapy for anal cancer in HIV patients causes prolonged CD4 cell count suppression. Ann. Oncol. 2012, 23, 141-147. [CrossRef]

61. Bryant, A.K.; Huynh-Le, M.-P.; Simpson, D.R.; Gupta, S.; Sharabi, A.B.; Murphy, J.D. Association of HIV Status With Outcomes of Anal Squamous Cell Carcinoma in the Era of Highly Active Antiretroviral Therapy. JAMA Oncol. 2018, 4, 120. [CrossRef]

62. Smith, D.M.; Salters, K.A.; Eyawo, O.; Franco-Villalobos, C.; Jabbari, S.; Wiseman, S.M.; Press, N.; Montaner, J.S.G.; Man, S.F.P.; Hull, M.; et al. Mortality among people living with HIV/AIDS with non-small-cell lung cancer in the modern HAART Era. AIDS Care 2018, 30, 936-942. [CrossRef]

63. Okuma, Y.; Hosomi, Y.; Imamura, A. Lung cancer patients harboring epidermal growth factor receptor mutation among those infected by human immunodeficiency virus. Onco Targets. Ther. 2015, 8, 111-115. [CrossRef] [PubMed]

64. Pillai, V.C.; Venkataramanan, R.; Parise, R.A.; Christner, S.M.; Gramignoli, R.; Strom, S.C.; Rudek, M.A.; Beumer, J.H. Ritonavir and efavirenz significantly alter the metabolism of erlotinib-An observation in primary cultures of human hepatocytes that is relevant to HIV patients with cancer. Drug Metab. Dispos. 2013, 41, 1843-1851. [CrossRef] [PubMed]

65. Rittmeyer, A.; Barlesi, F.; Waterkamp, D.; Park, K.; Ciardiello, F.; von Pawel, J.; Gadgeel, S.M.; Hida, T.; Kowalski, D.M.; Dols, M.C.; et al. Atezolizumab versus docetaxel in patients with previously treated non-small-cell lung cancer (OAK): A phase 3, open-label, multicentre randomised controlled trial. Lancet 2017, 389, 255-265. [CrossRef]

66. Herbst, R.S.; Baas, P.; Kim, D.-W.; Felip, E.; Pérez-Gracia, J.L.; Han, J.-Y.; Molina, J.; Kim, J.-H.; Arvis, C.D.; Ahn, M.-J.; et al. Pembrolizumab versus docetaxel for previously treated, PD-L1-positive, advanced non-small-cell lung cancer (KEYNOTE-010): A randomised controlled trial. Lancet 2016, 387, 1540-1550. [CrossRef]

67. Reck, M.; Rodríguez-Abreu, D.; Robinson, A.G.; Hui, R.; Csőszi, T.; Fülöp, A.; Gottfried, M.; Peled, N.; Tafreshi, A.; Cuffe, S.; et al. Pembrolizumab versus Chemotherapy for PD-L1-Positive Non-Small-Cell Lung Cancer. N. Engl. J. Med. 2016, 375, 1823-1833. [CrossRef]

68. Borghaei, H.; Paz-Ares, L.; Horn, L.; Spigel, D.R.; Steins, M.; Ready, N.E.; Chow, L.Q.; Vokes, E.E.; Felip, E.; Holgado, E.; et al. Nivolumab versus Docetaxel in Advanced Nonsquamous Non-Small-Cell Lung Cancer. N. Engl. J. Med. 2015, 373, 1627-1639. [CrossRef]

69. Brahmer, J.; Reckamp, K.L.; Baas, P.; Crinò, L.; Eberhardt, W.E.E.; Poddubskaya, E.; Antonia, S.; Pluzanski, A.; Vokes, E.E.; Holgado, E.; et al. Nivolumab versus Docetaxel in Advanced Squamous-Cell Non-Small-Cell Lung Cancer. N. Engl. J. Med. 2015, 373, 123-135. [CrossRef]

70. Huang, S.-H.; McCann, C.D.; Mota, T.M.; Wang, C.; Lipkin, S.M.; Jones, R.B. Have Cells Harboring the HIV Reservoir Been Immunoedited? Front. Immunol. 2019, 10, 1842. [CrossRef]

71. Mylvaganam, G.; Yanez, A.G.; Maus, M.; Walker, B.D. Toward T Cell-Mediated Control or Elimination of HIV Reservoirs: Lessons From Cancer Immunology. Front. Immunol. 2019, 10, 2109. [CrossRef] 
72. Kythreotou, A.; Mauri, F.A.; Shiner, R.; Suardi, E.; Dalla Pria, A.; Akarca, A.; Trivedi, P.; Gupta, N.; Marafioti, T.; Newsom-Davis, T.; et al. The influence of HIV status on programmed-death ligands expression in non-small cell lung cancer. Lung Cancer 2018, 115, S4. [CrossRef]

73. Domblides, C.; Antoine, M.; Hamard, C.; Rabbe, N.; Rodenas, A.; Vieira, T.; Crequit, P.; Cadranel, J.; Lavolé, A.; Wislez, M. Non-small cell lung cancer from HIV-infected patients expressed PD-L1 with marked inflammatory infiltrates. AIDS 2017, 32, 1. [CrossRef]

74. Scilla, K.A.; Zandberg, D.P.; Bentzen, S.M.; Mainor, C.; Heath, J.; Ioffe, O.B.; Cellini, A.L.; Edelman, M.J.; Riedel, D.J.; Feliciano, J.L. Case-control study of PD-1, PD-L1 and B7-H3 expression in lung cancer patients with and without human immunodeficiency virus (HIV) infection. Lung Cancer 2018, 123, 87-90. [CrossRef] [PubMed]

75. Castellanos, J.R.; Purvis, I.J.; Labak, C.M.; Guda, M.R.; Tsung, A.J.; Velpula, K.K.; Asuthkar, S. B7-H3 role in the immune landscape of cancer. Am. J. Clin. Exp. Immunol. 2017, 6, 66-75. [PubMed]

76. Okuma, Y.; Hishima, T.; Kashima, J.; Homma, S. High PD-L1 expression indicates poor prognosis of HIV-infected patients with non-small cell lung cancer. Cancer Immunol. Immunother. 2018, 67, 495-505. [CrossRef] [PubMed]

77. Hoffmann, M.; Pantazis, N.; Martin, G.E.; Hickling, S.; Hurst, J.; Meyerowitz, J.; Willberg, C.B.; Robinson, N.; Brown, H.; Fisher, M.; et al. Exhaustion of Activated CD8 T Cells Predicts Disease Progression in Primary HIV-1 Infection. PLoS Pathog. 2016, 12, 1-19. [CrossRef]

78. Pinato, D.; Kythreotou, A.; Mauri, F.; Suardi, E.; Allara, E.; Shiner, R.; Akarca, A.; Trivedi, P. Functional immune characterization of HIV-associated non-small-cell lung cancer. Ann. Oncol. 2018, 29, 1490. [CrossRef]

79. Cook, M.R.; Kim, C. Safety and Efficacy of Immune Checkpoint Inhibitor Therapy in Patients With HIV Infection and Advanced-Stage Cancer: A Systematic Review. JAMA Oncol. 2019, 5, 1049-1054. [CrossRef]

80. Uldrick, T.S.; Gonçalves, P.H.; Abdul-Hay, M.; Claeys, A.J.; Emu, B.; Ernstoff, M.S.; Fling, S.P.; Fong, L.; Kaiser, J.C.; Lacroix, A.M.; et al. Assessment of the Safety of Pembrolizumab in Patients With HIV and Advanced Cancer-A Phase 1 Study. JAMA Oncol. 2019. [CrossRef]

81. Bari, S.; Chan, A.; Jain, S.R.; Hostler, C.J. Outcomes of programmed cell death protein 1 (PD-1) and programmed death-ligand 1(PD-L1) inhibitor therapy in HIV patients with advanced cancer. J. Oncol. 2019, 2019. [CrossRef]

82. Spano, J.-P.; Veyri, M.; Gobert, A.; Guihot, A.; Perré, P.; Kerjouan, M.; Brosseau, S.; Cloarec, N.; Montaudié, H.; Helissey, C.; et al. Immunotherapy for cancer in people living with HIV. AIDS 2019, 33, F13-F19. [CrossRef]

83. Ostios-Garcia, L.; Faig, J.; Leonardi, G.C.; Adeni, A.E.; Subegdjo, S.J.; Lydon, C.A.; Rangachari, D.; Huberman, M.S.; Sehgal, K.; Shea, M.; et al. Safety and Efficacy of PD-1 Inhibitors Among HIV-Positive Patients With Non-Small Cell Lung Cancer. J. Thorac. Oncol. 2018, 13, 1037-1042. [CrossRef]

84. McCullar, B.; Alloway, T.; Martin, M. Durable complete response to nivolumab in a patient with HIV and metastatic non-small cell lung cancer. J. Thorac. Dis. 2017, 9, E540-E542. [CrossRef] [PubMed]

85. Guihot, A.; Marcelin, A.; Massiani, M.; Samri, A.; Soulie, C.; Autran, B.; Spano, J. Drastic decrease of the HIV reservoir in a patient treated with nivolumab for lung cancer. Ann. Oncol. 2018, 29, 517-518. [CrossRef] [PubMed]

86. Althoff, K.N.; Gebo, K.A.; Moore, R.D.; Boyd, C.M.; Justice, A.C.; Wong, C.; Lucas, G.M.; Klein, M.B.; Kitahata, M.M.; Crane, H.; et al. Contributions of traditional and HIV-related risk factors on non-AIDS-defining cancer, myocardial infarction, and end-stage liver and renal diseases in adults with HIV in the USA and Canada: A collaboration of cohort studies. Lancet HIV 2019, 6, e93-e104. [CrossRef]

87. Goedert, J.J.; Hosgood, H.D.; Biggar, R.J.; Strickler, H.D.; Rabkin, C.S. Screening for Cancer in Persons Living with HIV Infection. Trends Cancer 2016, 2, 416-428. [CrossRef] [PubMed]

88. National Lung Screening Trial Research Team; Aberle, D.R.; Adams, A.M.; Berg, C.D.; Black, W.C.; Clapp, J.D.; Fagerstrom, R.M.; Gareen, I.F.; Gatsonis, C.; Marcus, P.M. Reduced Lung-Cancer Mortality with Low-Dose Computed Tomographic Screening. N. Engl. J. Med. 2011, 365, 395-409. [CrossRef]

89. National Lung Screening Trial Research Team; Church, T.R.; Black, W.C.; Aberle, D.R.; Berg, C.D.; Clingan, K.L.; Duan, F.; Fagerstrom, R.M.; Gareen, I.F.; Gierada, D.S. Results of Initial Low-Dose Computed Tomographic Screening for Lung Cancer. N. Engl. J. Med. 2013, 368, 1980-1991. [CrossRef]

90. Makinson, A.; Eymard-Duvernay, S.; Raffi, F.; Abgrall, S.; Bommart, S.; Zucman, D.; Valour, F.; Cheret, A.; Poizot-Martin, I.; Duvivier, C.; et al. Feasibility and efficacy of early lung cancer diagnosis with chest computed tomography in HIV-infected smokers. AIDS 2016, 30, 573-582. [CrossRef] 
91. Shi, W.; Zhou, L.; Peng, X.; Ren, H.; Wang, Q.; Shan, F.; Zhang, Z.; Liu, L.; Shi, Y. HIV-infected patients with opportunistic pulmonary infections misdiagnosed as lung cancers: The clinicoradiologic features and initial application of CT radiomics. J. Thorac. Dis. 2019, 11, 2274-2286. [CrossRef]

92. Little, R.F. Cancer clinical trials in persons with HIV infection. Curr. Opin. HIV AIDS 2017, 12, 84-88. [CrossRef]

93. Uldrick, T.; Ison, G.; Rudek, M.; Noy, A.; Schwartz, K.; Bruinooge, S. Modernizing Clinical Trial Eligibility Criteria: Recommendations of the American Society of Clinical Oncology-Friends of Cancer Research HIV Working Group. J. Clin. Oncol. 2017, 35, 3774-3780. [CrossRef] [PubMed]

94. Suneja, G.; Boyer, M.; Yehia, B.R.; Shiels, M.S.; Engels, E.A.; Bekelman, J.E.; Long, J.A. Cancer Treatment in Patients With HIV Infection and Non-AIDS-Defining Cancers: A Survey of US Oncologists. J. Oncol. Pract. 2015, 11, e380-e387. [CrossRef] [PubMed]

(C) 2020 by the authors. Licensee MDPI, Basel, Switzerland. This article is an open access article distributed under the terms and conditions of the Creative Commons Attribution (CC BY) license (http://creativecommons.org/licenses/by/4.0/). 